\title{
RESULTS OF LIMITED SCALE TRIAL OF SULFMONZOL 5\%
}

\author{
B.Enkhtogtokh, B.Burenbaatar \\ Institute of Veterinary Medicine, MSUA \\ bburenbaatar@yahoo.com
}

\begin{abstract}
Results of experiments on the use of anthelminthic drug agianst helminths in sheep, goats and cattle reveal that preparation "Sulfmonzol 5\%" has relatively higher effectiveness (98.8-100.00\%) against helminths eggs in sheep and cattle at day 21 of the trial, while it is highly effective (98.1-100.0\%) against goat helminths at day 14 of the trial.
\end{abstract}

KEY WORDS: Albendazole sulfoxide, helminths, eggs

\section{INTRODUCTION}

One of the basic reasons, minimizing animal productivity and leading to morbidity and mortality is the diseases caused by parasites of animals.

More than $30 \%$ of all livestock populations in Mongolia are annually involved in anti-parasitic control measures and many hundred millions of tugrugs are spent for such measures, but incidences and prevalence of animal parasitic diseases remain not dropped in our country.

After it was first reported during 1960's that thiabendazole, which was effective and broad spectrum actions against helminthes, benzimedazoles such as parbendazole, kambendazole, mebendazole and oxibendazole started being produced. Although all compounds of benzimidazoles are similarly acting against

\section{MATERIALS AND METHODS}

After the use of preparation "Sulfmonzol 5\%" in doses of $0.5 \mathrm{ml} / 10 \mathrm{~kg}, 15 \mathrm{ml} / 10 \mathrm{~kg}$ and $1.55 \mathrm{ml} / 10$ $\mathrm{kg}$ in 15 sheep, 15 goats and 15 cattle, which were artificially infestated with helminths, fecal samples parasites, they differ with effects to be exerted on animal body.

Metabolites of albendazole are albendazole - SO and albendazole $-\mathrm{SO}_{2}$, and maximal concentrations of these compounds in the blood plasma occurred at hours 16 to 36 after oral administration of this preparation or generally they are withdrawn from animal body within 72 hours.

Study of effects of $5 \%$ suspension of albendazole sulfoxide against intestinal nematodes of 6 genera demonstrated that effectiveness against Haemonchus contortus is $95 \%$, effects against Ostertagia ostertagi, Trichostrongylus colubriformis, Cooperia oncophora and Oesphagostomum radiatum ranges from 99 to $100 \%$, and effectiveness against Fasciola hepatica in liver is $86 \%$.

were collected at days 3, 7, 14, 21, 28 and 45, helminths egg count was performed by method of Stoll (1923) using McMaster chamber, and 
effectiveness of the preparation model against helminths was estimated.

Preparation model against helminths was investigated in dose of $0.5 \mathrm{ml} / 10 \mathrm{~kg}$ in 3800 ewes,

\section{RESULTS OF THE STUDY}

Study results demonstrate that use of the preparation decreased the number of eggs per $1 \mathrm{~g}$ fecal mass by 80.35 to $85.23 \%$ from day 3 of the experiment, while it dropped by 98.02 to $100.00 \%$ at days 14 to 21 . At day 28 of the experiment, helminth egg count per $1 \mathrm{~g}$ fece increased slightly, while helminths egg counts per $1 \mathrm{~g}$ fece in both control and experimental group sheep are almost
870 sheep wethers, 1840 goat does, 600 goat wethers, 640 cows and 87 bullocks in Huijirt and Harhorin soums of Uvurkhangai aimag and Arhust soum of Tuv aimag.

the same at day 45 of the trial. Egg counts per $1 \mathrm{~g}$ fece of goats treated with "Sulfmonzol 5\%" reduced abruptly from day $7(91.2 \%)$ and no egg was detected at day 14 of the experiment, while no egg was detected by egg count per $1 \mathrm{~g}$ fece of cattle at day 21 of the experiment.

Table 1 Results of investigation of therapeutric effects of anthelminthic preparation in sheep, goats and cattle

\begin{tabular}{|c|c|c|c|c|c|c|c|c|c|c|c|c|c|c|c|}
\hline \multirow{3}{*}{$\begin{array}{l}\text { Gro } \\
\text { ups }\end{array}$} & \multirow{3}{*}{$\begin{array}{l}\text { No.of } \\
\text { No. of } \\
\text { animals }\end{array}$} & \multirow{3}{*}{$\begin{array}{l}\text { Dose and } \\
\text { Dose and } \\
\text { route }\end{array}$} & \multirow{2}{*}{\multicolumn{2}{|c|}{$\begin{array}{l}\text { Before the } \\
\text { treatment }\end{array}$}} & \multirow{2}{*}{\multicolumn{11}{|c|}{$\begin{array}{l}\text { After the treatment } \\
\text { (egg counts per } 1 \mathrm{~g} \text { fece) }\end{array}$}} \\
\hline & & & & & & & & & & & & & & & \\
\hline & & & Day 0 & $\%$ & 3 & $\%$ & 7 & $\%$ & 14 & $\%$ & 21 & $\%$ & 28 & $\%$ & $45 \%$ \\
\hline $\begin{array}{l}\text { Gro } \\
\text { up } 1\end{array}$ & 5 sheep & $\begin{array}{ll}0.5 & \mathrm{ml} / 10 \\
\mathrm{k} 1 & \end{array}$ & & 0.0 & 200.0 & 87.5 & 167.5 .0 & 89.3 & 36.4 & 98.0 & 16.3 & 98.2 & 365.0 & 69.5 & $1150-$ \\
\hline $\begin{array}{l}\text { Gro } \\
\text { up } 2\end{array}$ & 5 sheep & $1 \mathrm{ml} / 10 \mathrm{kl}$ & 1015.0 & 0.0 & 203.0 & 81.0 & 122.0 & 89.7 & 20.7 & 98.6 & 10.8 & 98.4 & 357.0 & 70.5 & $1185-$ \\
\hline $\begin{array}{l}\text { Gro } \\
\text { up } 3\end{array}$ & 5 sheep & $\begin{array}{ll}1.5 & \mathrm{ml} / 10 \\
\mathrm{k} 1 & \end{array}$ & 1140.0 & 0.0 & 176.9 & 88.6 & 115.0 & 89.0 & 17.0 & 99.4 & 0.0 & 100.0 & 326.0 & 77.9 & $1203-$ \\
\hline $\begin{array}{l}\text { Con } \\
\text { trol }\end{array}$ & 5 sheep & $\begin{array}{l}\text { Not } \\
\text { treated }\end{array}$ & 1269.0 & 0.0 & 1269.0 & & 1259.0 & 0.0 & 1260.0 & 0.0 & 1260.0 & 0.0 & 1265.0 & 0.0 & 1290 - \\
\hline $\begin{array}{l}\text { Gro } \\
\text { up } 1\end{array}$ & 5 goats & $\begin{array}{ll}0.5 & \mathrm{ml} / 10 \\
\mathrm{kl} & \end{array}$ & 860.0 & 0.0 & 109.0 & 83.0 & 72.0 & 90.6 & 4.5 & 99.0 & 1.2 & 99.1 & 155.1 & 80.0 & 1515.0 - \\
\hline $\begin{array}{l}\text { Gro } \\
\text { up } 2\end{array}$ & 5 goats & $1 \mathrm{ml} / 10 \mathrm{kl}$ & 910.0 & 0.0 & 99.0 & 89.0 & 91.2 & 87.3 & 15.0 & 99.2 & 6.0 & 98.6 & 100.5 & 85.0 & $1605.0-$ \\
\hline $\begin{array}{l}\text { Gro } \\
\text { up } 3\end{array}$ & 5 goats & $\begin{array}{ll}1.5 & \mathrm{ml} / 10 \\
\mathrm{kl} & \end{array}$ & 893.0 & 0.0 & 82.2 & 85.1 & 66.8 & 90.1 & 0.0 & 100.0 & 0.0 & 100.0 & 190.3 & 70.6 & $1555.0-$ \\
\hline $\begin{array}{l}\text { Con } \\
\text { trol }\end{array}$ & 5 goats & $\begin{array}{l}\text { Not } \\
\text { treated }\end{array}$ & 900.0 & 0.0 & 900.0 & 0.0 & 900.0 & 0.0 & 900.0 & 0.0 & 900.0 & 0.0 & 900.0 & 0.0 & $1560.5-$ \\
\hline $\begin{array}{l}\text { Gro } \\
\text { up } 1\end{array}$ & 5 cattle & $\begin{array}{ll}0.5 & \mathrm{ml} / 10 \\
\mathrm{k} 1 & \end{array}$ & 1061.0 & 0.0 & 210.0 & 75.0 & 120.0 & 82.0 & 13.5 & 95.5 & 7.7 & 99.9 & 241.8 & 74.0 & 1890.3 - \\
\hline $\begin{array}{l}\text { Gro } \\
\text { up } 2\end{array}$ & 5 cattle & $1 \mathrm{ml} / 10 \mathrm{kl}$ & 1065.0 & 0.0 & 200.0 & 84.4 & 90.0 & 90.2 & 15.1 & 94.4 & 13.0 & 95.5 & 183.4 & 80.5 & $1865.3-$ \\
\hline $\begin{array}{l}\text { Gro } \\
\text { up } 3\end{array}$ & 5 cattle & $\begin{array}{ll}1.5 & \mathrm{ml} / 10 \\
\mathrm{kl} & \end{array}$ & 1145.0 & 0.0 & 183.2 & 88.2 & 77.5 & 96.7 & 2.7 & 99.8 & 0.0 & 100.0 & 263.8 & 88.9 & $2032.5-$ \\
\hline $\begin{array}{l}\text { Con } \\
\text { trol }\end{array}$ & 5 cattle & $\begin{array}{l}\text { Not } \\
\text { treated }\end{array}$ & 1200.0 & 0.0 & 1200.0 & 0.0 & 1200.0 & 0.0 & 1200.0 & 0.0 & 1200.0 & 0.0 & 1200.0 & 0.0 & 1945.0 - \\
\hline
\end{tabular}

\section{CONCLUSIONS}

Preparation "Sulfmonzol 5\%" against helminthes of cattle and sheep has $98.03-100.0 \%$ effectiveness at day 21 of the experiment, while effectiveness of the preparation against helminthes in goats was $98.7-100.0 \%$ at day 14 of the experiment. 


\section{REFERENCES}

1. Baatar Ts, To issue of studying tapeworms in sheep and goats. Reports of MAS. №1. P 1822

2. Baatar Ts, Study of tapeworms in sheep and goats., Publications of RIAH. 1965. №13, p 39.

3. Byambaa B, Parasitic diseases of animals in Mongolia and methods of diagnosis, curing and prevention. UB 2003, p 60

4. Dashzeveg G. Mew species of roundworm in cattle. J.Agriculture №2, p 47-49

5. Lkhamsteren S. Helminths of cattle of dairy farms around Ulaanbaatar city and controlling measures, MSc thesis, 2006

6. Mendjargal D., Research report of development of method for progrnosis of helminthes in ruminants steppe region, 2003

7. Nilbaatar Ch., Diagnosis of helminthes in animals. 1988, J.Agriculture, №3, p 32-33
8. Andreeva N.K., Atlas of helminthes strongylates in ruminants in Kazakhstan, Tashkent. 1967.

9. Boev S.N., New pulmonary nematode of mountain goats Cystocaulus vseboloodvi. An-Kaz.SSR, In: Parasites. 1968,

10. Bondareva V.I., Coenurosis invasion in domestic and wild animals, Publ. AnKazSSR, Alma-Ata, 1963.

11. Gagarin M.G., To study of specificity of helminthes, Conf. VOG, 1965

12. Demidov N.V., Chlorofos for controlling helminthiases, J. Veterinary Medicine, 1967

13. Armi, H.S., Albendazole sulfonation by rat liver P-450c. 1988.

Mothe, O., Totis, J.Pharmacol. Exp. Ther. 246, pp. $758-764$. 